DE DE GRUYTER OPEN
Research Article

(C) 2017 Moksha Singh and Munmun Jha This is an open access article licensed under the Creative Commons Attribution-NonCommercial-NoDerivs License (http://creativecommons.org/licenses/by-nc-nd/3.0/).

\title{
The Special Status Conundrum and the Problem of Rehabilitation in Jammu and Kashmir
}

\author{
Moksha Singh \\ Assistant Professor, Dept of Humanities and Social Sciences, \\ National Institute of Technology, Raipur, India \\ Munmun Jha \\ Professor of Sociology, Dept of Humanities and Social Sciences, \\ Indian Institute of Technology, Kanpur, India
}

Doi: $10.1515 / \mathrm{mjss}-2017-0025$

\begin{abstract}
The political crisis in the Indian state of Jammu and Kashmir, following the partition of the sub-continent, resulted in state-society construction that was embedded in religious, ethnic and ideological lines. Coupled with specially designed legislative and political framework, the final status of the state was marred with inbuilt ambiguities. The latter subsequently provided a foundation for further political destabilization in the region. The present contention on the status of Jammu and Kashmir within the Indian union is the outcome of one such temporary political adjustment that was implemented in the state in the form of Article 370 of the Constitution of India. This, over the years, has resulted in political upheaval, growth of secessionist feelings and violence in the state. The relief and rehabilitation of those affected by the conflict have suffered at the hands of this political adjustment. Article 370 does not allow for the implementation of various central government laws and policies in the state, preventing many from receiving the much deserved state and central government aid. This paper proposes that under Section 9 of the State's Constitution, changes should be brought about in this political adjustment so that there is an all inclusive policy on rehabilitation, ending the conundrum over who is benefitted and who is not.
\end{abstract}

Keywords: Jammu and Kashmir, special status, armed conflict, rehabilitation

\section{Background}

The princely state of Jammu and Kashmir, a conglomeration of many smaller kingdoms, was ethnically the most diverse and geographically the largest among the 562 states that the British had created in the Indian subcontinent (Bose 1997; DasGupta 2002; Groenhout, 2006), mainly through indirect rule. The partition of the sub-continent into two dominions i.e. India and Pakistan in 1947 significantly influenced the political discourse in the region. As far as India was concerned, the states were free to join either of the dominions by executing an Instrument of Accession or else stay independent. The ruler of Jammu and Kashmir who initially opted for an independent state later acceded to India following a tribal attack at the behest of Pakistan (Menon, 1955; Dasgupta, 2002; Kapur and Ganguly, 2012). This agreement was formalized between the two by signing the Instrument of Accession on 26 October 1947. It was a unique document in many respects that formed the basis of Jammu and Kashmir's future relationship with India. The Instrument of Accession accorded the state a "special status" and which was circumscribed by several 
stipulations that have an exhaustive bearing on its polity and society (Punjabi, 1995).

In May 1949 the representatives of the state government and the government of India agreed that the Constituent Assembly would decide about the transfer of power to the Indian Union. Accordingly, the "transitional and provisional" Article 370 was incorporated in the Indian constitution. However, this did not end the uncertainty over the final status of the state (Noorani, 2011; Agarwala, 2015). The two major reasons were: first, the accession was subject to a referendum or plebiscite and second, the issue of the future of the state was internationalized with the intervention of the United Nations Security Council for a peace settlement (Puri, 2008; Kumar, 2009). ${ }^{1}$ Since then, the Constitution of India has been subjected to various ideological interpretations (Sagar, 2015) and hence, varied contested solutions (Lamb, 1991; Bose, 2003; Ali et al, 2011; Dulat, 2015). Article 370, thus, has been a source of constant political crisis over the years and remains the cornerstone of many ambiguities on Kashmir (Singh, 1998; Mattoo, 2013, Chowdhary, 2016).

\section{Special Status: Article 370}

Part XXI of the constitution of India deals with the "Temporary, Transitional and Special Provisions." It describes Article 370 as a temporary provision and addresses three key points. First, it notifies that Article 238, dealing with the administration of states is not applicable to the state of Jammu and Kashmir. ${ }^{2}$ Second, the power of the parliament to make laws for the state is limited. Third, concurrence and consultation with the state is necessary on matters specified in the Instrument of Accession (Constitution of India, part XXI). The words "consultation" and "concurrence" used in Article 370 are significant as these carefully and deliberately seek to preserve the autonomous character of the state. ${ }^{3}$

In accordance with this special status, Jammu and Kashmir's relationship with India has been defined by a limited applicability of the Constitution of India and a conditional jurisdiction of the union parliament (Teng, 1990; Noorani, 2000). It has also been claimed by some commentators that under Article 368 the relation between Jammu and Kashmir and India can be altered only by an order of the President under Article 370 and in concurrence with the state government and its ratification by its constituent assembly. Since the State Constituent Assembly no longer exists, this provision, it is contended, has become inoperative. Article 368 which stipulates amending provisions of the Constitution, applicable to other states, thus stands defunct in the case of Jammu and Kashmir. Therefore, unilateral abrogation of Article 370 by the union parliament cannot take place (Noorani, 2000; Noorani, 2011).

Article 370 , as initially incorporated in the Constitution of India, had the following six special provisions which provided the legal framework for protecting the autonomy of Jammu and Kashmir. First, it provided that Jammu and Kashmir could have its own constitution within the Indian union, a

\footnotetext{
${ }^{1}$ Even after the accession of Jammu and Kashmir to India, Pakistani troops and raiders continued to occupy the region. India lodged a complaint with the Security Council on 1 January 1948, which led to India offering a plebiscite under the condition that Pakistan would withdraw its troops and raiders. Thus, the UN Resolution of 13 August 1948 declared that a plebiscite shall be conducted in the state to determine the status of Jammu and Kashmir but with a limited choice of opting to be either part of India or of Pakistan.

${ }^{2}$ Article 238 consists of provisions that deal with the administration of states in Part B of the First Schedule of the Indian Constitution. It was removed by the $7^{\text {th }}$ Constitutional Amendment Act, 1956, as the states were getting reorganized.

${ }^{3}$ Autonomy can be defined as "emerging patterns of new spaces in politics, spaces that speak of rights, and justice, the plank for these rights" (Samaddar, 2005, p.9). When applied in constitutional terms, autonomy allows for independent powers to make legislation on various subjects. Accordingly, in this particular case many stipulations result in no or limited powers to the Indian government in bringing change to the existing relation with Jammu and Kashmir. For example, as per clause 3 of Article 370 the President may, by public notification, declare that this Article shall cease to be operative but only on the recommendation of the Constituent Assembly of the State.
} 
state flag, and an anthem. ${ }^{4}$ Second, the Indian parliament's executive powers over Jammu and Kashmir was limited to three subjects i.e., defence, external affairs and communications, although there was scope for extending it to other subjects under certain circumstances. ${ }^{5}$ Third, if under certain circumstances, the powers of the union were to be extended, prior "concurrence" of the government of Jammu and Kashmir was required. Fourth, the concurrence was also provisional, as it had to be ratified by the state's constituent assembly. Fifth, the authority of the state government to give the "concurrence" would last only until the state's constituent assembly "is convened." Sixth, Article 370 (3) empowers the president of India to make an order abrogating or amending it. But for this too, "the recommendation" of the state's constituent assembly "shall be necessary before the President issues such notification" (Noornani, 2000).

Beginning 1954, the state witnessed greater assimilation with the Indian Union through various ratifications and amendments (Pramanik and Roy, 2013). India brought 42 constitutional orders and, therefore, a greater part of the union constitution now applies to the state with certain modifications and exceptions. This includes 260 out of the 395 articles and seven out of 12 schedules. So, the jurisdiction of the parliament now stands extended from the initial three subjects (Chowdhary, 2000). The greater assimilation of Jammu and Kashmir, brought about by the application of provisions of the Constitution of India to the state, aided in the implementation of certain institutional safeguards. However, it was also regarded as a process leading to the erosion of Article 370 (Noorani, 2011; Cottrell, 2013), causing "abuse" to the special status accorded to the state (Noorani, 2000) and resulting in socio-political instability in the state.

The ratifications and amendments increased the jurisdiction of the Supreme Court, the election commission ${ }^{6}$, various labour welfare measures etc in the state. However, even after the implementation of these enactments and inclusion of Jammu and Kashmir as the $15^{\text {th }}$ state in the First Schedule of the Constitution, the Indian parliament still cannot extend all its laws to it. ${ }^{7}$ Article 370 is a grim reminder of a sensitive link between India and Jammu and Kashmir (Pramanik and Roy, 2013; Kulshrestha, 2016) and the state government is entitled to govern with noticeable exclusions of laws regarding uniform civil code, suspension of the constitution, certain emergency provisions, permanent resident provisions, ownership of property, refugee status, etc. ${ }^{8}$

Over the years, both the constitutional exemptions and the alterations to Article 370 have not helped the social, economic and political development of the state ${ }^{9}$ (Mattoo, 2013; Sehgal, 2013; Wani, 2014). Various factions have continued to put their assertion over Article 370 and corresponding solution to the Kashmir crisis (Hewitt, 2002; Kumar, 2002; Chadda, 2006). Pakistan

\footnotetext{
${ }^{4}$ The Provisions of the State Constitution (except those relating to the relationship of the state with the Union) may be amended by an Act of the Legislative Assembly of the state passed by not less than two-thirds of its membership.

${ }^{5}$ Under Article 246 of the Indian Constitution, Parliament alone can make laws. These are enumerated in List IUnion List, List III- Concurrent List and List II- the State List. In the case of Jammu and Kashmir there is no State list. Until 1963 the Parliament could legislate on subjects contained in the Union List. However, it had no jurisdiction in case of Concurrent List under 7th Schedule of the Constitution. In the following years, the Parliament could also legislate on subjects of Concurrent List. The Parliament, however, cannot legislate on Preventive Detention laws for the state. The residuary powers, unlike other states, rests with the state.

${ }^{6}$ Elections to the State Legislature are, however, held under the provisions of the Constitution of Jammu and Kashmir.

${ }_{7}$ Ministry of Home Affairs, Government of India, "Annual Report 2006-07," http://mha.nic.in/pdfs/ar0607Eng.pdf.

${ }^{8}$ Also, Directive Principles of State Policy may be deemed inoperative in Jammu and Kashmir as Article 31C is not applicable to that State. Directive Principles of State Policy which includes establishing a uniform civil code (Part IV of the Indian Constitution) were not applicable to Jammu and Kashmir. The pre-1953 period witnessed non-application of all Parts - I to IV, Parts VI to X, Part XIII, Part XIV and Part XVIII of the Constitution. Further, under the provisions of Article 370, national emergency under Article 352 of the Constitution and financial emergency under Article 360 cannot be declared in the State.

${ }^{9}$ For example Article $31 \mathrm{C}$, forbids challenge on certain grounds to laws giving effect to Directive Principles of State Policy given in Part IV of the Constitution of India. Article 134A that empowers the High Courts to allow for appeal to the Supreme Court, and Article 373 which empowers the President to take decisions on persons under preventive detention in certain cases; do not find place in the Constitution of Jammu and Kashmir.
} 
carries forward its agenda of getting control over Kashmir, the seeds of which were sown following legitimization of religious identity as the basis of partition of the subcontinent and hence its claim over the Muslim majority state of Jammu and Kashmir (Groenhout, 2006). On the other hand, India's efforts for inclusive development and assimilation has caused unrest among a section of the the Kashmiri population (Ganguly and Bajpai, 1994; Wirsing, 2007 et al; Bose, 2003; Nandal, 2011), resulting in a shift towards separatist ideology (Habibullah, 2008; Peer and Rahman, 2012). Such political intricacies have brought disharmony in the region resulting in strife, ideological fix, three full scale wars between India and Pakistan, militarization and insurgency in the Kashmir valley, killings and disappearances, displacement, high levels of psychological stress, developmental stagnation, etc and a prolonged unresolved conflict in the state (Punjabi, 1992; Desmond, 1995; Ganguly, 1997; Ganguly, 2001; Cohen, 2003; Human Rights Watch, 2006; Médecins Sans Frontières, 2006; Jong et al, 2008; Amnesty International, 2011; Rather, 2013; Pandita, 2017).

\section{Article 370, Armed Conflict and Rehabilitation}

As discussed already, the status of Jammu and Kashmir has remained controversial since 1947. The political developments in the state led to a "separate ethno-national consciousness" emerging in the Valley which blew into a "full-blown secessionist movement" during the late 1980s (Ganguly, 2001). The late 1980s ushered in an era of violence resulting in socio, economic and political instability in the state. Some highly publicized killings of Kashmiri Pandits, as part of the agenda of ethnic cleansing by the insurgents, created fear among the community which was forced to migrate out of the valley to various parts of Jammu region and the rest of India (Bose, 2003; Bakaya and Bhatti, 2005). It is estimated that the total number of such families were 56,246 (Government of India, 2004), which meant over 400,000 Kashmiri Pandits. This comprised "over 95 per cent of their original population in the Valley" (Gill, 2001).

Violence by the insurgents in the state resulted in counter-insurgency operations (Meyerle, 2003) leading to allegations of rights violation involving killings, rape etc (Sebastian, 1996), enactment of laws that threatened the physical integrity of the civilian populations such as the Disturbed Areas Act of 1976 and the Armed Forces (Jammu and Kashmir) Special Powers Act 1990 (AFSPA) ${ }^{10}$, Public Safety Act, 1978 (PSA) ${ }^{11}$

As per the reports of Jammu and Kashmir government, about 39,918 people lost their lives from 1990 to April 2011. This was the combined sum of 13,226 civilians; 5,369 security force personnel and 21,323 terrorists. In contrast to these figures, Kashmir's main separatist group - the All Parties Hurriyat (Freedom) Conference claims that more than 100,000 died in violent incidents in the state by 2008 (Reuters, 2008). The South Asian Terrorism Portal puts this number around 44,235 from 1988-2017 (South Asia Terrorism Portal, 2017). It was also claimed that by the time insurgency related incidents had receded to some extent, more than 15,000 houses had been torched and more than 3,000 people had been killed while in custody. Approximately the same numbers had 'disappeared' (Lifschultz, 2002).

Consequently, the political turmoil in Jammu and Kashmir with the particular nature of conflict involving high levels of material destruction, a huge loss of life and phenomenal displacement has affected the civilian population immensely. The impact of the armed conflict has been compounded by other factors such as poverty, lack of state-based social welfare measures, abuses of civil and political rights, environmental fragility and diminishing cultural practices.

In response to the growing needs of the population affected by armed conflict in Jammu and Kashmir, the state and the central governments initiated various welfare programmes and policies. In late 1990s various plans and policies were initiated to specifically cater to the needs of those

\footnotetext{
${ }^{10}$ It gave the security forces exceptional powers of search and arrest without warrants and detention.

${ }^{11}$ Unlike the National security Act 1980 (NSA) applicable in other parts of India that limits detention to a maximum period of one year, the PSA provides for detention for a maximum of two years. Until 2011, a total of 8000-20,000 people were detained under PSA in Jammu and Kashmir (Amnesty International, 2011) (Kashmiri, 2011).
} 
affected by conflict. One such measure was the establishment of the Rehabilitation Council of Victims of Militancy in Jammu and Kashmir in February 1996. It is now known as the Council for Rehabilitation of Widows, Orphans, Handicapped and Old Persons. Through its various schemes, the Council aimed at providing relief and immediate succour to the victims of militancy which included the disabled, widows, orphans, old men and women of the affected families. The aid was mainly in the form of financial assistance meant to be utilized for the psychological rehabilitation of victims of conflict, marriage of young widows and grown-up daughters, and pension to widows, elderly parents and the disabled. ${ }^{12}$ The state government also introduced the "Healing Touch Policy" with the intention of reintegrating those who had joined various militant outfits and resorted to violence. It allowed the release and surrender of the terrorists, with the promise of providing them with jobs (Bhan, 2014; Chandran, 2016).

The central government also took certain initiatives. The Prime Minister's Reconstruction Plan of 2004 announced an outlay of approximately Rs. 24,000 crore, which included providing relief and rehabilitation to those displaced and the families of the victims of militancy (Jammu and Kashmir Government, Planning and Development Department, 2004). Apart from this, a comprehensive package was also announced by the prime minister in April 2008 as part of the confidence building measures. It included the return and rehabilitation of Kashmiri migrants who had left their homes in the wake of terrorist violence in the state, cash compensation of Rs 5 lakh to the families of those killed in acts of violence, employment of one member of the affected families, enhancement of pension to widows of civilians killed in militancy related violence, financial assistance for the education of those orphaned in militant violence, and a package for 1947 West Pakistan Refugees $(\text { WPRs })^{13}$ comprising measures aimed at facilitating admission of their wards in professional and other educational institutions, bank loans without mortgage for taking up self-employment or business activities, and vocational training for the youth. Recently the government has announced a package of Rs. 2000 crore for refugees from Pakistan Occupied Kashmir to meet their outstanding needs in respect of allotment of land and related rehabilitation measures (Hindustan Times, 2016).

\section{Problems and Limitations}

The policies drafted by the state and central governments for the rehabilitation of the victims of conflict appear to be promising. However, many problems arise during the implementation and execution of these policies. For instance, the state follows a separate set of laws based on Article 370 for its residents. Therefore, it becomes mandatory for an individual to prove that he is a permanent resident in Jammu and Kashmir in order to secure benefits from the rehabilitative policies. The individuals who fail to produce a Permanent Resident Certificate (PRC) (discussed later) are disqualified from making such claims. Unfortunately, a large number (mostly children with killed parents) have either lost their certificates in violence related incidents or could not undergo the certification process because of various administrative hurdles. Even those who posses it, have to undergo a rigorous documentation and multi-window departmental verification process. This often delays the aid in reaching the affected population, thereby minimizing its relevance.

Additionally, rehabilitation is further restricted as several of the union laws that are indispensable in maintaining transparency and accountability of the process are not applicable in the state. Also, an abundance of laws and legislative stipulations restrict the entry of national and international non-governmental organizations (intending to provide support to the affected population) into the state.

\footnotetext{
${ }^{12}$ The financial aid included pension to widows and old persons to the tune of Rs. 500 per month, marriage assistance of Rs 10,000 to young widows and grown-up daughters of older widows, pension (Rs 500) to handicapped and disabled persons, scholarship to the children for professional studies (Rs. 5000 per year for tuition fee and Rs 7000 as hostel maintenance).

${ }^{13}$ During the 1947 Partition riots, a chunk of the population migrated from the present Sialkot district of Punjab province of Pakistan to Jammu and Kashmir. As the WPRs had come from outside J\&K territory, they were not given the PRC. WP refugees have Indian citizenship and can vote in the parliamentary elections. But they do not have the right to vote in assembly elections as they have not been given citizenship in Jammu and Kashmir.
} 


\section{The State Subject Law, Women, Children and Refugees}

Part III of the constitution of Jammu and Kashmir refers to the issue of "permanent residents". ${ }^{14}$ It describes permanent residents as those who on 14 May 1954 were a state subject of Class I or Class ${ }^{11}{ }^{15}$ and had lawfully acquired immovable property in the state. It also included those who had migrated after 1 March 1947 to the territory now included in Pakistan and had returned to the state under a permit for resettlement or for a permanent return in accordance with any law made by the state legislature (Constitution of Jammu and Kashmir). ${ }^{16}$

However, PRC came with restrictions for specific groups. For example, in the case of females, the Jammu and Kashmir High Court ruled in 1965 that women after marriage shall adopt the domicile and nationality of their husbands, and hence would lose various rights provided to a Permanent Resident of the state under Section 6 of the state constitution. ${ }^{17}$ This was in violation of Article 14 and 15 of the Indian Constitution and Section 5 of Jammu and Kashmir Constitution that grants equal rights. This ruling was challenged; in 2004 the High Court overruled its previous order and stated categorically that the daughter of a permanent resident of Jammu and Kashmir shall not lose her permanent resident status after her marriage with a person belonging to another state (Chhibber, 2013).

This was once again challenged in the High Court in 2013 when a petition was filed challenging the clause that off-springs and husband of a woman marrying a non-state subject shall not be entitled to the same status and therefore cannot own immovable property or other benefits in Jammu and Kashmir (Fayyaz, 2013; Sethi, 2013). This is a worrying situation especially for women who were married outside the state by families fearing their safety. Kashmiri Pandit women, whose families sought refuge outside the state following targeted violence, suffered the most and have little to gain from the rehabilitative policies of the state.

Most of these policies proved eyewash for the majority of affected women, especially widows. By 2008, Jammu and Kashmir reported 32,000 women who were rendered widows as a result of the conflict in the state (Dabla, 2009). This figure does not include countless half-widows ${ }^{18}$ who had to undergo immense economic, legal, social and psychological implications arising out of the situation (Qutab, 2012). Further, Jammu and Kashmir reports a total of 2,00,000 orphans of which 37 percent are considered to be the creation of the ongoing conflict in the state (Shafi, 2014). Many among them do not possess PRC. They have either lost it due to incidents involving violence such as gutting of the house, material damage, migration, loss of parents, etc. and which directly renders them ineligible to claim government aid. The Council for Rehabilitation of Widows, Orphans, Handicapped and Old Persons provides relief only to the registered persons. Thus, incomplete documentation disqualifies many children, women and men from the benefits of the rehabilitative

\footnotetext{
${ }^{14}$ In 1890, the then Maharaja had instituted a law disallowing outsiders from owning land and property in the state. This law was further strengthened by Maharaja Hari Singh by a Notification dated 20 April 1927 which provided certain safeguards and privileges for the permanent residents of the state.

${ }^{15}$ Class I - All persons born and residing within the state before the commencement of the reign of Maharaja Gulab Singh and also persons who settled therein before the commencement of the year 1942, and have since been permanently residing therein. Class II -All persons other than those belonging to Class I who settled within the State before the close of the year 1968, and have since permanently resided and acquired immovable property therein.

${ }^{16}$ Thus, special rights have been granted to the "permanent residents" or the "state subjects" of Jammu and Kashmir which include the right to employment, acquisition of immovable property, making claims to other forms of aid as the state government may provide, and eligibility to vote in the state legislative assembly elections. Consequently, persons who are not "permanent residents" do not enjoy these privileges.

${ }^{17}$ These included: right to immovable property, right to a job, to vote in assembly elections etc. While issuing Permanent Resident Certificate to women a condition was put i.e. "Valid Till Marriage". In order to give it a final legal status, the state government brought the Permanent Resident (Disqualification) Bill, 2004 so that women marrying outside the state are disqualified as residents (Daily Excelsior, 6 March 2004, p.1.). However, due to stiff opposition from various quarters this controversial Bill was deferred by the Legislative Council of Jammu and Kashmir.

${ }^{18}$ This terminology is coined for those Kashmiri females whose husbands have disappeared during the turmoil in the state.
} 
measures adopted by the state and the centre.

From 1996-2012, the number of beneficiaries who received aid from the Council were only 6870 (Council for Rehabilitation of Widows, Orphans, Handicapped and Old Persons, 2012). When this figure is compared with the total number of direct and indirect victims of conflict in the state, the effort seems insignificant. The data suggests that the administration has been unable to reach out to the vast majority waiting for relief and rehabilitation. Further, in the action plan 2016-17, a total of 1964 orphans received aid (Daily Excelsior, 2016) when the number of such children reported in the state is much higher. The lack of adequate outreach has generated further problems for the victims. For example, children not receiving aid in most of the cases land up in orphanages across the state.

There is another group that has suffered immensely because of the Permanent Resident statute. The state accounts for 1.5-10 lakh post-partition refugees called the West Pakistan Refugees (WPRs). This figure, however, is contested by various sources (Ahmad, 2016; Naqash, 2017). ${ }^{19}$ Even after 70 years of their migration, they are still regarded as refugees and denied the status of permanent residents of Jammu and Kashmir. They are without citizenship rights under the provisions mentioned in the Article $370 .^{20}$ They can vote in the parliamentary elections but not in the state assembly elections (Chowdhary, 2016). Further, their regular demand for a similar rehabilitation package as that of the migrant Kashmiri Hindus has been rejected. They, however, were promised employment opportunities, admission to professional institutions outside the state and bank loans without the provision of land mortgage. Most of these refugees continue to live in border areas, receiving little attention from the state (Singh, 2008; Dubey, 2016).

\section{Documentation and Bureaucracy}

For a victim of armed conflict, securing any benefit from the government sponsored schemes turns out to be a multifarious, multi-department activity which is often exhaustive and time taking. For example, after producing the "permanent resident" proof, the victim has to undergo further documentation. First, he has to obtain a non-involvement certificate duly certified by the state police stating that their relatives were not directly or indirectly associated with any militancy related activity. This is virtually impossible for those whose relative(s) were killed by the security forces or during crossfire between the militants and the security forces. In the case of school going children, in addition to the non-involvement certificate, a date of birth certificate issued by the municipal corporation or a magistrate, and a school certificate is mandatory. Second, a copy of the First Information Report (FIR) lodged at the concerned police station about the incident too is required, failing which the person is debarred from getting the benefits. The FIR is usually missing in most of the cases. It is observed that the people who have lost a family member or a relative in an incident relating to violence are in no state to lodge an FIR. The absence of any of the stated documents disqualifies the claimant from receiving aid, thus hindering the process of rehabilitation.

Further, accountability of the administrative machinery remains questionable; quite often the desired information cannot be obtained as various legislations such as the Central Right to Information Act (RTI) $2005^{21}$ have not been extended to Jammu and Kashmir in its entirety, owing to the special status it enjoys under Article 370. Though the Jammu and Kashmir Right to Information Act $2009^{22}$ exists, it is only a watered down version of the central law. This Act is regarded as eyewash by various rights groups as it does not offer much transparency (Commonwealth Human Rights Initiative, 2016). The reasons being that various public institutions

\footnotetext{
${ }^{19}$ In the wake of the tribal invasion and the India-Pakistan partition in 1947, many Pakistan-Occupied-Kashmir (PoK) refugees or the WPRs migrated to the border districts of Jammu province.

${ }^{20}$ Permanent Resident Certificate (PRC) is given to people whose ancestors have lived in the State for at least 10 years before 14 May 1954.

${ }^{21}$ Under the provisions of the Act, any citizen of India may request information from a "public authority" (a body of Government or "instrumentality of State") which is required to reply expeditiously or within thirty days. The Act also requires every public authority to computerise their records for wide dissemination and to proactively certain categories of information so that the citizens need minimum recourse to request for information formally.

${ }^{22}$ This can be accessed at - http://jksic.nic.in/Pages/JK-RTI-Act-2009.PDF
} 
are excluded from its ambit; the definition of 'information' is vague ${ }^{23}$; it seeks reasons for accessing information; it involves long waiting period for obtaining information; and so on.

The Protection of Human Rights Act, $1993^{24}$ provides for the State Human Rights Commission (Universal Law Publishing, 2011). However, the Jammu and Kashmir State Human Rights Commission does not have adequate powers and is marred with ambiguities. Often the positions of officials of the commission remain vacant and it is the police agency of the state that takes over the cases. This is against the principle of natural justice and which fosters the idea of nemo judex caus sua $^{25}$ (Shayiq, 2013; Bhatt and Qazi, 2008). Similarly, the Prevention of Corruption Act, 1988 and the Commissions of Inquiry Act, 1952 are analogous but do not correspond to the Central Acts. ${ }^{26}$

Many other Central legislations such as the Orphanages and Other Charitable Homes (Supervision and Control) Act, 1960, ${ }^{27}$ Women's and Children's Institutions (Licensing) Act, 1956, ${ }^{28}$ etc. find no place in the state. Many orphanages report cases of the "other orphans," ${ }^{29}$ who have been institutionalized even when their parents are alive. In most cases, the orphanages encourage the placement of the children in child care institutions as there are monetary benefits involved. Due to the absence of Central laws for monitoring such institutions in the state, many orphanages with minimum infrastructural facilities have led to the unwanted institutionalization of the children. Also, the scenario makes it difficult to inspect and monitor the performance of the orphanages and to revoke their licenses if required.

\section{Conclusion}

Keeping in view the current socio-political status of the state, the central government has been providing Jammu and Kashmir with continuous financial support over and above the usual central plan assistance. In terms of policy, the state of Jammu and Kashmir receives special treatment from the central government. This financial outpouring, if utilized judiciously along with the state's policies towards the welfare of the conflict affected population, can ensure effective and speedy rehabilitation.

These measures, however, require a re-analysis and re-modeling of the entire process of rehabilitation. The mechanism can be made easier by introducing single-window clearance system and lessening the burden of documentary proof. The state must devise ways to accommodate and rehabilitate those who are left out of the process because of the provisions made under Article 370 .

\footnotetext{
${ }^{23}$ The definition in the Central RTI Act is much wider and covers a whole gamut of materials which qualify to be called 'information' - this includes records, circulars, memos, emails, log books, contracts emails, opinions, press releases, reports and models. In the absence of a comprehensive definition of the term 'information' in this manner, bureaucrats are likely to deny access to many categories of information whose disclosure may be inconvenient to their vested interests.

${ }^{24}$ It provided for the constitution of National Human Rights Commission, State Human rights Commissions in States, human Rights courts for protecting the human rights in India.

${ }^{25}$ It states that the person whose own cause is violated cannot become a judge.

${ }^{26}$ In place of the Prevention of Corruption Act, 1988, Jammu and Kashmir has the Prevention of Corruption Act, 2006. The commissions of Inquiry Act, 1952 can be applied in Jammu and Kashmir only in matters pertaining to List I and List III in the Seventh Schedule to the Constitution as applicable in the state.

${ }^{27}$ The Orphanages and Other Charitable Homes (Supervision and Control) Act, 1960 (Act no. 10 of 1960) was enacted with the view to have supervision and control over orphanages and homes working for those women and children who are being neglected.

${ }^{28}$ The Women's and Children's Institutions (Licensing) Act, 1956 (Act no. 105 of 1956) provide for the licensing of institutions for women and children. It prescribes the conditions subject to which license may be granted and the guidelines for the management of institutions and the reception, care, protection and welfare of women and children in institutions, including all matters relating to their diet, clothing, accommodation, training and general conduct; the inspection of institutions; the discharge from institutions of women and children and their transfer from one institution to another. It extends to the whole of India except the State of Jammu and Kashmir.

${ }_{29}$ Other orphans or the non-orphans are children whose primary caregivers were alive but were put in orphanages because of various social circumstances and economic hardships that arose out of the conflict in the state. These included cases where the parents had lost their sources of income (livestock, land, etc.), had re-married, abandoned the children, were receiving constant threats from the militants or had sustained a physical injury during acts of violence and, therefore, unable to look after the child.
} 
A more humanistic and non-discriminatory approach towards its residents would make the process of rehabilitation more effective.

Even if the state government does not want to forego Article 370 in its entirety as it allows Jammu and Kashmir to maintain its autonomous status within the Indian union, at least necessary changes can be brought about in this political adjustment so that the rehabilitation process does not suffer and the affected population is benefitted. For instance, there must be flexibility in terms of determining the Permanent Resident status of a person. As long as Kashmir was a princely state, the law acted as a mechanism to prevent the British colonial power from establishing their presence in the state. However, in the changed political environment, instead of protecting the rights of those affected by the conflict, it acts as a barrier in the rehabilitation process of its population, especially women, children and refugees. This also becomes important in the context that the final political solution to Kashmir crisis may take many years or even decades. However, the people who are victimized, i.e. women, children, refugees and migrants because of the prevailing political instability in the state, should not suffer and get their fair share of rehabilitative measures on time. At least their basic rights to education, physical and mental health, employment, shelter, etc are not compromised.

Section 9 of the State's Constitution empowers the Jammu and Kashmir legislature to make laws on: (a) altering the definition of a 'permanent resident' (b) conferring on 'permanent residents' any special rights or privileges, and (c) in regulating or modifying any special rights or privileges enjoyed by 'permanent residents'. Therefore, if the government wants, a special clause can be added to Article 370 that makes the process of granting PRC to the affected population more flexible. This will be a matter of much relief to the large population of conflict affected groups that cannot put forward any claims to the rehabilitation process. This will allow and ensure an all inclusive policy on rehabilitation, ending the conundrum over who is benefitted and who is not.

\section{References}

Agarwala, J.S. (2015). Article 370 of the constitution a genesis. Economic and Political Weekly, 1(16), 25-27.

Ahmad, M. (2016, December 28). Victims of political grandstanding, Pakistan refugees trigger new controversy in Kashmir. The Wire, Retrieved from https://thewire.in/90083/kashmir-refugees-domicile-certificatepakistan-india/

Ali, T., Bhatt, H., Chatterji, A.P., Mishra, P., \& Roy, A. (2011). Kashmir the case of freedom. London, England: Verso.

Amnesty International. (2011). A Lawless Law: Detention Under the Jammu and Kashmir Public Safety Act. London, UK: Author.

Bakaya, P., \& Bhatti, S. (2005). Kashmir conflict: A study of what led to the Insurgency in Kashmir valley \& proposed future solutions. California, US: American Institute of International Studies.

Bhan, M. (2014). Counterinsurgency, democracy, and the politics of identity in India: From warfare to welfare? New York, US: Routledge.

Bhatt, I.H., Qazi K.A. (2008). Analysis of the provisions of the Protection of Human Rights Act, 1993 - A plea for its active working in Jammu \& Kashmir state. In B.P.S. Sehgal (Eds). Human Rights in India - Problems and Perspectives (561-565). New Delhi, India: Deep and Deep Publications Pvt Ltd.

Bose, S. (1997). The challenge in Kashmir - Democracy, self-determination ad a just peace. New Delhi, India: Sage Publications.

Bose, S. (2003). Kashmir: Roots of conflict, paths to peace. New Delhi, India: Vistaar.

Cabinet approves Rs 2000 crore aid for refugees from Pakistan-Occupied Kashmir. (2016, December 1). Hindustan Times, Retrieved from http://www.hindustantimes.com/india-news/cabinet-approves-rs-2-000crore-aid-for-refugees-from-pakistan-occupied-kashmir/ story-Mon1zG7wfqVOKNEVqPcCxN.html.

Chadda, M. (2006). Minority rights and conflict prevention: Case study of conflicts in Indian Jammu and Kashmir, Punjab and Nagaland. London, UK: Minority Rights Group International.

Chandran, S. (2016, August 31). Healing touch 2.0. The Hindu, Retrieved from http://www.thehindu.com/op inion/columns/Healing-Touch-2.0/article14598302.ece

Chhibber, M. (2013, December 3). Explained: Do J\&K women lose their right to share in ancestral property if they marry a non-state subject? Indian Express, Retrieved from http://archive.in dianexpress.com/news/explained-do-j-k-women-lose-their-right-to-share-in-ancestral-pro perty-if-theymarry-a-nonstate-subject-/1202457/.

Chowdhary, R. (2000). Autonomy demand: Kashmir at crossroads. Economic and Political Weekly, 35(30), 
2599-2603.

Chowdhary, R. (2016). Jammu and Kashmir: Politics of identity and separatism. Oxon, UK: Routledge.

Cohen, S.P. (2003). India, Pakistan and Kashmir. In S. Ganguly (Eds). India as an Emerging Power (32-60). London, UK: Frank Cass Publishers.

Commonwealth Human Rights Initiative. (2016). State Level RTI: Jammu and Kashmir. Retrieved from http://www.humanrightsinitiative.org/content/state-level-rti-jamm u-and-kashmir.

Constitution of India. Part XXI.

Cottrell, J. (2013). Kashmir: The vanishing autonomy. In Y. Ghai \& S. Woodman (Eds). Practicing selfgovernment: A comparative study of autonomous regions. Cambridge, UK: Cambridge University Press. doi.org/10.1017/CBO9781139088206.006.

Council for Rehabilitation of Widows, Orphans, Handicapped and Old Persons. (2012). Physical and Financial Achievements. Retrieved from http://jksrc.nic.in/pfa.html

CS Reviews Working of State Rehabilitation Council. (2016, December 15). Daily Excelsior, Retrieved from http://www.dailyexcelsior.com/cs-reviews-working-state-rehabilitation-council/.

Dabla, B. (2009). A sociological study of widows and orphans. New Delhi, India: Jay Kay Books.

Dasgupta, C. (2002). War and diplomacy in Kashmir 1947-48. New Delhi, India: Sage Publications.

Desmond, E. (1995). The insurgency in Kashmir (1989-1991). Contemporary South Asia 4(1), 5-12.

Dubey N (2016, December 26). West Pakistan refugees in J-K 'empty-handed' even after 70 years after independence. Hindustan Times, Retrieved from http://www.hindustantimes.com/india-news/west-pak istan-refugees-in-j-k-empty-handed-even-70-years-after-independence/story-Vf3eeYCbvskr ykOyi7bFLI.html

Dulat, A.S., \& Sinha, A. (2015). Kashmir: The Vajpayee years. Noida, India: HarperCollins.

Fayyaz, A.A. (2013, December 7). J\&K State-subject law on property rights challenged afresh in HC. The Hindu, Retrieved from http://www.thehindu.com/news/national/jk-statesubject-law-on-property-rights-challengedafresh-in-hc/article5431349.ece.

Ganguly, R. (1997). The move towards disintegration: explaining ethno secessionist mobilization in South Asia. Nationalism and Ethnic Politics, 3(2), 101-130.

Ganguly, R. (2001). India, Pakistan and the Kashmir insurgency: Causes, dynamics and prospects for resolution. Asian Studies Review, 25(3), 309-310.

Ganguly, S. \& Bajpai, K.. (1994). India and the crisis in Kashmir. Asian Survey, 34(5), 401-416.

Gill, K.P.S. (2001). The Kashmirir Pandits: An ethnic cleansing the world forgot. Retrieved from http://www.satp.org/satporgtp/kpsgill/2003/chapter9.htm

Government of India. (2004). Annual Report 2003-04. New Delhi, India: Ministry of Home Affairs.

Groenhout, F. (2006). The history of the Indian princely states: Bringing the puppets back onto centre stage. History Compass, 4(4), 629-644.

Habibullah, W. (2008). My Kashmir conflict and the prospects of enduring peace. Washington D.C., US: United States Institute of Peace Press.

Hewitt, V. (2002). An area of darkness, still? The political evolution of ethnic identities in Jammu and Kashmir, 1947-2001. In S. Fenton and S. May (Eds). Ethnonational identities ((129-158). New York, US: Palgrave MacMillian.

Human Rights Watch. (2006, September). Everyone lives in fear patterns of impunity in Jammu and Kashmir. Human Rights Watch, 18(11C). Retrieved from https://www.hrw.org/report/2006/ 09/11/ everyone-livesfear/patterns-impunity-jammu-and-kashmir.

India revises Kashmir death toll to 47, 000. (2008, November 21). Reuters, Retrieved from http://in.reu ters.com/article/2008/11/21/idINIndia-36624520081121.

Jammu and Kashmir Government, Planning and Development Department (2004). Prime Minister's Reconstruction Plan (PMRP). Retrieved from http://www.jandkplanning.com/index.php? option=com_content\&view=article\&id=192\&ltemid=72\&lang=en.

Jong, K., Ford, N., Kam, S., Lokuge, K., Fromm, S., Galen, R., Reilley, B., \& Kleber, R. (2008). Conflict in the Indian Kashmir valley I: Exposure to violence. Conflict and Health, 2(10). doi: 10.1186/1752-1505-2-10.

Kapur, S.P., \& Ganguly, S. (2012). The jihad paradox: Pakistan and Islamist militancy in South Asia. International Security, 37(1), 111-141.

Kashmiri, I.S. (2011, May 31). Draconian law prevailing in our state (Jammu and Kashmir). Frontline Kashmir, Retrieved from http://www.frontline kashmir.org/ 2011/05/draconian-laws-prevailing-in-our-state.html.

Kulshreshtha, P. (2016). Article 370: Constitutional obligation and compulsion. International Journal of Language, Literature and Humanities, 4(1), 94-112.

Kumar, R. (2002). Untying the Kashmir knot. World Policy Journal, 19(1), 11-24.

Kumar, R. (2009). Negotiating peace in deeply divided societies: a set of simulations. New Delhi, India: Sage Publications India Pvt. Ltd.

Lamb, A. (1991). Kashmir: A disputed legacy, 1846-1990. London, UK: Roxford Books.

Lifschultz, L. (2002 August). Death in Kashmir: Perils of 'self-determination. Economic and Political Weekly, 
37(31), 3229.

Mattoo, A. (2013, December 6). Understanding Article 370. The Hindu, Retrieved from http://www.thehindu. com/opinion/lead/Understanding-Article-370/article11640894.ece

Médecins Sans Frontières. (2006). Kashmir: Violence and health. Amsterdam: Author.

Menon, V.P. (1955). The story of the integration of the Indian states. Retrieved from https://hidf1.files.wordpress.com/2011/02/the-story-of-the-integration-of-the-indian-state s-by-v-pmenon.pdf.

Meyerele, G. (2003). Conflict Escalation in Kashmir: A Study in State-Society Breakdown (Unpublished master's thesis). University of Virginia, Charlottesville, USA.

Nandal, RS. (2011, June 20). State data refutes claim of 1 lakh killed in Kashmir. The Times of India, Retrieved from http://timesofindia.indiatimes.com/india/State-data-refutes-claim-of-1-lakh-killed-inKashmir/articleshow/8918214.cms

Naqash, R. (2017, January 2). Move to issue identity certificates to West Pakistan refugees may lead to fresh unrest in Kashmir. Scroll.in, Retrieved from https://scroll.in/article/825542/move-to-issue-identitycertificates-to-west-pakistan-refugees-may-lead-to-fresh-unrest-in-kashmir.

Noorani, A.G. (2000, September). Article 370: Law and politics. Frontline, 17(19), Retrieved from http://ww w.frontline.in/static/html/fl1719/17190890.htm.

Noorani, A.G. (2011). Article 370: A constitutional history of Jammu and Kashmir. Oxford, UK: Oxford University Press.

Pandita, R. (2017, April 14). Kashmir: The price of soft secessionism. Open, Retrieved from http:/l www.openthemagazine.com/article/politics/kashmir-the-price-of-soft-secessionism.

Peer, G., \& Rahman, J. (2012). An unpleasant autonomy: Revisiting the special status for Jammu and Kashmir. Economic and Political Weekly, 47(23), 72-75.

Pramanik, S. \& Roy, T.K. (2013). Game theoretic model to the Jammu-Kashmir conflict between India and Pakistan. International Journal of Mathematical Archive 4(8), 162-170.

Punjabi, R. (1992). Kashmir: The bruised identity. In R.G.C. Thomas (Eds). Perspective on Kashmir: The roots of conflict in South Asia (144-145). Boulders, Colorado: Westview Press.

Punjabi, R. (1995). Kashmir imbroglio: the socio-political roots. Contemporary South Asia, 4(1), 39-53.

Puri, B. (2008). Kashmir Insurgency and After. New Delhi, India: Orient Longman Private Limited.

Qutab, S. (2012). Women victims of armed conflict: Half-widows in Jammu and Kashmir. Sociological Bulletin, 61(2), 255-278.

Rather, F.A. (2013). Armed conflicts in J\&K and its impact on society. A case study of Kashmir valley. International Journal of Scientific and Research Publications, 3(2), 1-3.

Sagar, D. (2015). Jammu \& Kashmir - A victim. New Delhi, India: Prabhat Prakashan.

Samaddar, R. (2005). The Politics of autonomy - Indian experience. New Delhi, India: Sage Publications.

Sebastian, P.A. (1996, February). Kashmir behind the propaganda curtain. Economic and Political Weekly, 31(6), 319-321.

Sehgal, N. (2013). A state in turbulence - Jammu and Kashmir. New Delhi, India: Ocean's Books (P) Ltd.

Sethi, S.R.P. (2013, December 3). Women's rights in J\&K. Daily Excelsior. Retrieved from http://www.dailyexcelsior.com/womens-rights-in-jk/.

Shafi, S. (2014, July 21). Kashmir's orphan girls. Aljazeera, Retrieved from http://www.Aljazeera.com/inde $\mathrm{p} \mathrm{t} \mathrm{h}$ /inpictures/2014/06/pictures-kashmir-orphan-girls-201462711251151349.html.

Shayiq, F.I. (2013). The Jammu \& Kashmir Protection of Human Rights Act, 1997: A critical evaluation. International Journal of Innovative Research \& Development, 2(5), 33-45.

Singh, G. (2008) Human rights and J\&K refugees of 1947 partition. In B.P. Singh Sehgal (Eds). Human rights in India: Problems and perspectives (pp. 566-581). New Delhi, India: Deep and Deep Publications.

Singh, N. (1998). Cultural conflict in India: Punjab and Kashmir. In B. Crawford \& R.D. Lipschutz (Eds). The myth of "ethnic conflict": Politics, economics, and "cultural" violence (pp. 320-352). Berkeley, California: UC Berkeley International and Area Studies Press.

South Asia Terrorism Portal. (2017). Annual Fatalities in Terrorist Violence 1998-2017. Retrieved from http://www.satp.org/satporgtp/countries/india/states/jandk/data_sheets /annual_casual ties.htm.

Teng, M.K. (1990). Kashmir - Article 370. New Delhi, India: Anmol Püblications.

Universal Law Publishing (2011). The Protection of Human Rights Act, 1993. New Delhi, India: Author.

Wani, A.A. (2014, September 29). [Review of book Article 370: A constitutional history of Jammu and Kashmir, by AG Noorani]. Race \& Class, 56(2), 93-95.

Wirsing, R., Schaffer, T.C., Ganguly, S., Sharma, S. \& Behera, N.C. (2007, January). Navnita Chadha Behra's Demystifying Kashmir. [Review of Demystifying Kashmir, by Navnita Chadha]. Asia Policy 3, 187-205. 